\title{
Internal and external heat load with fire fighter protective clothing: data from the lab and the field
}

\author{
Simon Annaheim*, Fabio Saiani, Marc Grütter, Piero Fontana, Martin Camenzind, Rene Rossi \\ From 15th International Conference on Environmental Ergonomics (ICEE XV) \\ Portsmouth, UK. 28 June - 3 July 2015
}

\section{Introduction}

Protective clothing for fire fighters is characterized by high thermal insulation to reduce external heat gain through dry and wet heat $[1,2]$. However, these protective properties limit heat dissipation from the human body and impede thermoregulation $[3,4]$. As a result, fire fighters suffer from non-compensable heat stress during physical activity especially when exposed to a harsh environment [5]. However, there is little data available about the effect of internal and external heat load on whole-body thermo-physiological responses when wearing protective clothing. This study provides data of a lab trial including physical activity and a field test conducted in a fire chamber.

\section{Methods}

The lab trial (climatic chamber, $\mathrm{n}=10$ participants) included two exposures to $40{ }^{\circ} \mathrm{C}$ ambient temperature including physical activity (treadmill with 3.3 and 5 Mets) of 20 min duration with a recovery phase of 20 min duration at $25{ }^{\circ} \mathrm{C}$ in between. The field trial (fire chamber, $\mathrm{n}=9$ participants) consisted of an exposure to a mean (SD) temperature at $1 \mathrm{~m}$ above ground level of $141(18){ }^{\circ} \mathrm{C}$ for 15 min without any kind of activity. As for the lab trial, two exposures were separated by a recovery phase of $15 \mathrm{~min}$ duration at $25{ }^{\circ} \mathrm{C}$. In both investigations, rectal temperature $\left(\mathrm{T}_{\mathrm{re}}\right)$, heart rate $(\mathrm{HR})$ and sweat water loss (change in body mass) were measured. Mean skin temperature $\left(\overline{\mathrm{T}}_{\mathrm{sk}}\right)$ was calculated according to EN ISO 9886 based on temperature measures at 8 body sites [6].

\footnotetext{
* Correspondence: simon.annaheim@empa.ch

Laboratory for Protection and Physiology, Empa, St. Gallen, Switzerland
}

\section{Results}

In the lab and field trials respectively, similar changes in rectal temperature were observed for the first $(+0.15$ $(0.05){ }^{\circ} \mathrm{C} .10 \mathrm{~min}^{-1}$ and $\left.+0.17(0.11){ }^{\circ} \mathrm{C} .10 \mathrm{~min}^{-1}\right)$ and the second exposure $\left(+0.28(0.07){ }^{\circ} \mathrm{C} .10 \mathrm{~min}^{-1}\right.$ and +0.29 $\left.(0.13){ }^{\circ} \mathrm{C} .10 \mathrm{~min}^{-1}\right)$. The maximum values for both trials are shown in table 1 .

\section{Discussion}

Maximum physiological responses during the fire chamber trial were more pronounced as for the climatic chamber trial. This observation underlines the importance of fire fighter protective clothing in harsh conditions. However, changes in thermo-physiological responses were found to be similar for the lab and the field trial.

\section{Conclusions}

Our findings highlight the importance of the thermophysiological impact of protective clothing during activity. Increased physical activity itself can lead to non-compensable heat stress when wearing protective clothing, even though the environmental condition is not expected to induce severe heat stress.

Table 1. Mean (SD) maximum values observed during lab and field tests

\begin{tabular}{|c|c|c|c|c|}
\hline & $\mathrm{T}_{\mathrm{re}}\left[{ }^{\circ} \mathrm{C}\right]$ & $\overline{\mathrm{T}}_{\mathrm{sk}}\left[{ }^{\circ} \mathrm{C}\right]$ & HR [bpm] & Sweat loss [kg] \\
\hline $\begin{array}{l}\text { Climatic } \\
\text { chamber trial }\end{array}$ & $38.1(0.3)$ & $37.0(0.2)$ & $139.1(17.3)$ & $0.9(0.2)$ \\
\hline $\begin{array}{l}\text { Fire chamber } \\
\text { trial }\end{array}$ & $38.6(0.3)^{* *}$ & $41.8(1.0)^{* * *}$ & $164.6(13.7)^{* *}$ & $1.2(0.3)^{*}$ \\
\hline
\end{tabular}




\section{References}

1. Rossi R, et al: Hot steam transfer through heat protective clothing layers. Int J Occup Saf Ergon 2004, 10(3):239-45.

2. Morel A, et al: A review of heat transfer phenomena and the impact of moisture on firefighters' clothing and protection. Ergonomics 2014, 57(7):1-12.

3. Cheung SS, et al: The thermophysiology of uncompensable heat stress. Physiological manipulations and individual characteristics. Sports Med 2000, 29(5):329-59.

4. Holmér I: Protective clothing in hot environments. Ind Health 2006, 44(3):404-413.

5. Cheung SS, et al: Physiological strain and countermeasures with firefighting. Scand J Med Sci Sports 2010, 20(3):103-16.

6. EN ISO 9886: Ergonomics - Evaluation of thermal strain by physiological measurements. 2004.

doi:10.1186/2046-7648-4-S1-A100

Cite this article as: Annaheim et al: Internal and external heat load with fire fighter protective clothing: data from the lab and the field. Extreme Physiology \& Medicine 2015 4(Suppl 1):A100.

\section{Submit your next manuscript to BioMed Central} and take full advantage of:

- Convenient online submission

- Thorough peer review

- No space constraints or color figure charges

- Immediate publication on acceptance

- Inclusion in PubMed, CAS, Scopus and Google Scholar

- Research which is freely available for redistribution

Submit your manuscript at www.biomedcentral.com/submit 